\title{
(NATIONAL) CANON, (NATIONAL) THEATRE AND (NATIONAL) IDENTITY: A DEBATE OVER A 1928 BÁNK BÁN-MISE EN SCÈNE IN HUNGARY
}

\author{
ZOLTÁN IMRE \\ University of Veszprém, Veszprém, \\ Hungary
}

\begin{abstract}
I would not suppose that the excellent, scholarly and well-educated director of the national theatre, the classical consignatory and home of Hungarian theatrical literature and public spirit, would touch József Katona's masterpiece with profane hands. (That's right! That's right!) Not a single letter must be added, not a word must be taken away from it. Otherwise Katona would be turning over in his grave. I can understand that the director of the national theatre would like to redirect the play in series of performances; to change and synchronise that masterpiece with the taste of the contemporary decadent and sick psyche, and - I would say - with the rotten morals of the contemporary era; to make Katona's masterpiece a hugely popular and literary success. Instead of these changes, however, I would rather say that Katona's masterpiece should remain unperformed. Let it be a book of prayers for the inhibitors of the peaceful and sorrowful Hungarian settlements, the Hungarian intellectuals who would rather read it in silence; and then mourn, be passionate, and contemplate silently on its eternal values. But that masterpiece cannot be put on the most important stage of the nation in an altered form. I think it would be an assault against the living conscience of the Hungarian nation. (That's right! That's right!) I would not question the good will of the director of the national theatre, but it is impossible to carry out such an assault. (Agreement all around.)
\end{abstract}

(quoted in Németh 1935:185 - my translation, Z. I.)

The above speech was delivered by Gábor Jánossy, a member of Parliament, in the Hungarian Houses of Parliament on 26 October 1928. His protest was provoked by an interview with Sándor Hevesi, the Hungarian National Theatre's director, which had been published few days earlier in the Pesti Napló (Pest Journal) on 21 October 1928. In that interview Hevesi announced that he would at-

Hungarian Studies 15/1 (2001)

0236-6568/2001/\$5.00 @ 2001 Akadémiai Kiadó, Budapest 
tempt to make dramaturgical changes in and re-direct József Katona's play, Bánk bán. Apart form the MP, several well-known Hungarian writers, scholars of literature, literary historians, politicians, public figures, high-ranked officials, editors of popular magazines, and journalists expressed their opinions about Hevesi's plan (see-é-á 1928). Exceptional as such in the history of the Hungarian theatre, the debate over a mise en scène of a dramatic text was connected to various symbolic and real territories, institutional relations, and power structures. These included: the (national) canon, the (national) theatre, (national) politics, as well as authorisation, legitimisation and (national) identity. This paper will focus on the debate and its interconnected fields. It will examine some aspects of canonisation and the theatre through the example of a classical text, the Bánk Bán; and the theatre's attempt to perform this play in the specific cultural, political, and social context of Hungary of the late 1920s.

\section{Canon and National Canon}

In Das kulturelle Gedächtnis, Jan Assmann argues that the concept of canon is central for the investigation of the mechanisms and channels of cultural continuity. ${ }^{1}$ Assmann differentiates between the ancient (Babylonian, Summer, Hebrew) and the later clerical use of canon. The etymology of the word, kanón, goes back to a sort of reed, which was appropriate for straight beams and columns, and reveals that it was basically the instrument of architecture. From the concrete meaning, the figurative meanings were arranged around four focus points: 1 . measure, direction, criteria; 2. example, model; 3. rule, norm; 4. table, list (Assmann 1992:107). The first meaning was used in art as a metric system in which the proportion of details and the whole gives an absolute calculable form and also makes the whole a regularised and normative system. Here the rigour of the form and ability for continuity were connected and the principle of canon fulfilled its function by classical "mimesis, aemulation, imitatio" (Assmann 1992:108). In the second sense, canon indicates the frontiers to which one can go within defined institutional law or ethical norm. The third sense designates that canon defines and fixes the norms and rules, while the fourth refers to the astronomers' and chronographers' lists as the symbolic order of time and history. From these Assmann concludes that the instrumental criteria was decisive in its ancient use as it was considered as an instrument of orientation, which made available of punctuality, and gave definite references and directions (Assmann 1992:112).

In the $4^{\text {th }}$ century $\mathrm{AD}$, however, the concept of canon, though still kept its ancient meanings, was changed. The debates over the canonical texts and their inter-

pretations ended with the Catholic council's decisions, which summarised the list of sacred and authoritative texts and their interpretations. That list was also called 
canon. Here, however, as Assmann reminds us, the term referred to the concept of a set of texts which became the principle of compulsory power, basement of everything, and former of existence - the idea of the textual canon was thus born (Assmann 1992:114). Though canon lost its instrumental quality, its semantic field was widened a long the line of normativity and the category of general values and validity. The instrumental sense was replaced with the theological as the idea of "sanctity" was attached to it. For Assmann, the canon was regarded as "sacred." On the one hand, it possesses absolute authority and compulsory power; on the other, it commands untouchability (Assmann 1992:116). Therefore, a canonical text is and represents authority, gained by tradition and/or declaration by the power of authority; and prescribes that it cannot be changed and/or altered.

Though the contemporary use of the term is still based on the sacred tradition of the textual sense, canon can also be defined as a term argues Mihály SzegedyMaszák that "stands for a standardized corpus ... with rules of its own" (SzegedyMaszák 1990:17). Here, corpus is much wider then the list of texts, as it refers to texts, pictures, films, theatrical performances, pieces of music, etc., and their verbal and non-verbal interpretations, organised in the form of lists, systematically organised along the line of certain rules. That implies the concept of canon as list and as system.

Canon as list is considered as a carefully selected list of the great masterpieces of culture and tradition. These masterpieces are considered to possess formative and normative values, authoritative power; and they are displayed as examples and models. The researcher's task is to analyse these masterpieces and to define how and why exactly that list of texts has evolved.

Although the study of the list of great masterpieces is part of our inheritance from positivism, which emphasised collecting of data, ordering it, and then drawing conclusions from the material; the idea of the canon also refers to a principle "beyond" or "outside" the texts included in the list, to something as György Kálmán C. points out transcends, transforms them like traditions, values, ethics, esthetical qualities or similar principles. These, however, refer to a system beyond the texts (Kálmán C. 1998:253). That system can be modelled as a lingual one, the Saussuerian langue, as a sort of knowledge beyond the individual utterances, or masterpieces as Kálmán C. did it (Kálmán C. 1998:253-4). In this respect canon however as the stack of selected great masterpieces belongs to the sphere of system and can also be considered as Mihály Szegedy-Maszák argues as "cultural grammar" (Szegedy-Maszák 1992:119).

For Szegedy-Maszák, the canon not only defines the cultural artefacts that possess unquestionable values, it also mediates knowledge and embodies history. The canon is a fixed tradition in which certain texts and their interpretations become selected and established as models. The examples are considered valuable to preserve for a certain interpretative community. For that community, the canon cre- 
ates and preserves knowledge, value-system, and interpretative customs as well as strategies. Moreover, it has an important function in the creation and establishment of the identity, self-respect and self-representation of a certain community (Szegedy-Maszák 1992:120-126).

In his article "Kánon és trópus", Gábor Bezeczky argues that canon cannot be simply considered as a list of texts and authors, brought together by chance, but must be seen as a system with its own rules and inner structure, which define what can be included and the relations among its elements. The canon as system works by reduction and selection as it stands for literature, modelling the wholeness of literature (Bezeczky 1998:266). The canon can only be a part of literature. But as the relationship between the two is metonimical and synechdochal, the canon can be considered as the representation of literature as such. Though Bezeczky applied it only to texts and literature, the concept of representation of the canon can also be extended to other fields. Through its great masterpieces, the canon represents literature, music, theatre, film, painting, sculpture, etc. as such. Moreover, in an even wider sense, the representative function of canon can also be utilised for the formation, maintenance, and reform of certain virtual and real communities.

The model setting, direction giving, value preserving, and representative function of canon was also utilised for the formation of national communities. As Benedict Anderson has remarked, the formation of a nation implies an obvious problem deriving from the fact that it is "an imagined political community, as we can only imagine that it can be confined by nature as a sovereign entity" (Anderson 1983:15). A nation forms a real community only in the imagination, since its members do not connect to each other with real links in their everyday lives, and there is no physical space where a whole nation can be found and seen together. In The Body of Spirit, Allucquere Rosanne (Sandy) Stone calls those communities virtual where the physically separated members are connected through mutual beliefs and practices (Stone 1995:298). Thus, nation can only be realised as a virtual community. For the creation, maintenance, self-definition of such a community a nation needs the $\operatorname{link}(\mathrm{s})$ between the physically separated individuals to be presented and manifested through various means.

The link is supposed to be based on a collective identity that is shared by most of the members of the community. That collective identity is to be evolved from the past. The past, however, does not exist in itself, but as Jan Assmann rightly claims that "the past ... comes into being at all, when one gets into connection with it." 2 The past has to be constructed un/consciously through the selective process of remembering and forgetting in a retrospective way. The past is remembered collectively and socially in a collective memory that is active backwards and forwards, because memory does not only reconstruct the past, but organises how to experience present and future (Assmann 1992:35-43). The past, however, cannot 
be "authentically" reconstructed in its complexity. Thus, it is re-constructed again and again from and in the present and is constantly utilised for the present. The past serves as legitimisation, reinforcement for and - or symbol for the lack - of the present, and basis for the future.

Although Assmann also mentioned that memory needs locations and has a tendency for localisation (Assmann 1992:39), it was Pierre Nora who argued in detail that for remembering the past, a community needs certain means which he calls the 'places of memory' (lieux de mémoire) (Nora 1984). The creation of these places results from a process in which the spontaneous and privately lived individual memories are transformed into collective history. The places of historical remembrance can be manifested in various forms as institutions, topographical sites, objects, cultural creations, canons, social habits, even buildings. Just as the places of memory, canon cannot be realised and maintained without its own places, such as schools, libraries, journals, universities, and theatres. Though it depends on and is legitimised by the power of the places, these places also depend on and are legitimised by the power of the canon (Szegedy-Maszák 1992:128 130). Therefore, these places are connected to power and can also be considered as the instruments of power. These symbolic, real or even virtual places are utilised not only for memory, but as places on and in which cultural/national identity can be confirmed in the present and projected onto the future by certain performative manoeuvres, which refer to various, but not stable, symbolic meanings.

In the nineteenth century, an authentic community came to be considered as organised on a national basis, and the establishment of the national canon was one of the (obvious) means for its justification. Since then canon and national identity have been merged. Their merge is not static, however, because canon is (re)created when traditions are fragmented and values are polarised, when it is to (re)decide the order to be followed. In these cases the canon (re)claims itself to be the most appropriate tradition, based on universal ratio and/or power of divine declaration. Those who accept a canon accept a sort of formative and normative self-definition. Therefore, the acceptance of a canon is at the same time the acceptance of a collective identity defined by the canon as a set of sacred masterpieces, rules, and values. The canon establishes and forms collective national identity. "The sanctification of a given tradition [as canon] always aims at the sanctification of a given community. Thus the canon becomes ... the survival strategy of cultural identity."'3 Therefore, canon not only establishes a national community by providing it with an identity, but a canon can also serve as the depository of evidence testifying to the survival of that community under (foreign) oppression. Moreover, it possesses the possibility to change and/or alter that identity by changing and/or altering the canon. 


\title{
Theatre and National Theatre
}

Theatre is very often defined as the interpretation and/or adaptation of a certain text. This text-based approach focuses above all on the dramatic text and then focuses on the various presentations or dramatizations of the text, namely its appearance in changing performances. In this way theatre is identified exclusively with the performance. Parallel to that approach, theatre is often defined as a building where dramatic texts are performed. Neither of these definitions, however, takes into consideration the complexity of theatre. The definitions emphasize only certain aspects of theatre: the dramatic text, or the building, or the performance. Nevertheless, theatre is multifunctional and works simultaneously on multiple layers. Its multifunctionality and various levels can be approached through its various relations. First, theatre can be understood in terms of process: process between text, if any, and performance, performance and audience, and audience and text. Second, theatre may be viewed as an institution with its own structural and hierarchical relations and supported by and reflecting on society. Third, theatre may also be seen as a phenomenon, which is deeply rooted in the social, cultural, historical, ideological and political network of a given society. A national theatre is both multifunctional and multiple layered because the concept of the theatre of a nation is methonimic: what is presented in and by it serves (supposedly and intentionally) as the expression(s) and representation(s) of a nation.

Investigating the notion of theatre of a nation and its relation to cultural legitimisation, Loren Kruger based her analyses on the assertion in The National Stage that

\begin{abstract}
the notion of staging the nation, of representing as well as reflecting the people in the theatre, of constituting or even standing in for an absent or imperfect national identity, emerges in the European Enlightenment and takes concrete shape with the Revolutionary fêtes (Kruger 1992:3).
\end{abstract}

After this general statement, however, Kruger focuses on merely three countries, England, France, and the United States because for her the full force of that "notion" emerges only with the rise of mass politics. What she is thus interested in is a phenomenon, which she calls "theatrical nationhood," that "manifested itself fully in the course of the nineteenth century with the rise of the mass party politics, 'universal' (male) suffrage, and the demand of the people for legitimate representation as protagonist on the political stage" (Kruger 1992:3). Therefore, she only deals with relatively late realisations of the notion of a national theatre in functioning and independent states (France) within imperial context (the United States) and when the imperial context had just been lost (England). 
In other countries of Europe, however, national theatres were established much earlier. Among the first ones, the Hamburg theatre, which was established in 1767, and came to be utilised as an institution of German cultural identity and values; and as a phenomenon for expressing the will to unite the separate small German states (Carlson 1989a:94 and Brown 1995:292-294). In Austria - following the practice established by Frederick the Great of Prussia as early as the 1740s in Berlin (see Carlson 1989b:73-74) - it was also the central authority that established its national theatre when the Burgtheatre was renamed as the Austrian National Theatre by Joseph II in 1776. As part of the ruler's reforms, the multifunctional nature of the theatre was utilised by Joseph II. His aim was not only to establish territorial integrity but also to integrate the multicultural territories and multilingual ethnic groups into a centralised, modernised and fully bureaucratised civil state under the rule of the Austrian Monarchy (Simhandl 1999:182-191).

While the notion of the national theatre was regarded as one of the means for the integration of an empire in the countries of Western Europe, in Eastern Europe the debates over and later the realisation of the national theatre took place within the context of an oppressive imperium; and the national theatre was utilised for uniting and preserving the nation. Here, national theatre was conceived and later employed for creating and maintaining national identity, national culture and a national state.

Analysing the basic practical premises of forming a national state in the nineteenth century, Eric J. Hobsbawn argued in Nations and Nationalism Since 1780 that people who did not posses an independent territory and functioning administrative institutions were supposed to create these through cultural institutions and practices (Hobsbawn 1997:50-53). In the Hungarian context such "substitute" cultural institutions and practices were also important. As early as the second decade of the nineteenth century the importance of national language was recognised by the so-called "neologist" movement, which was spearheaded by leading Hungarian writers and thinkers. They thought that Hungarian needed to be modernised in order to be able to express properly the ideas of contemporary everyday life. Since language could serve as one of the links between the members of the virtual national community, it soon came to be seen by contemporaries as the 'key factor' for national survival. Language, through literature, could also be utilised as one of the basic propagators of a mythical national past and the formation of a desired future. The official language had been Latin, but German was widely used; and among the aristocracy French had also been fashionable. As a result the renewal of Hungarian was also seen, especially by the censors of the Habsburg monarchy, as a sign of passive resistance against Austrian political leadership as well as against Austrian, German, and French cultural influences. Hungarian has 
kept these functions ever since, and the importance of Hungarian has often been (over)emphasised, especially when the territorial integrity, sovereignty, cultural heritage of Hungary were/are (or felt to be) threatened.

In addition to language and literature, and often in connection to them, physical objects, institutions, and sites have also been transformed into symbolic means, into "places of memory". These places were semiotised, providing symbolic meanings for the national past and present. Institutions such as the Hungarian Academy of Sciences (1825), the National Museum and Library (1808), or even a bridge across the Danube (Lánchíd 1842-48), in addition to their obvious practical and modernising functions, were seen as monuments to express the power and the values of the nation - and their founders - by means of their size, design, ornamentation and, not least, their location. These newly established institutions in Pest-Buda included the Hungarian, later national, theatre, which came to be seen as one of the sites for cultural performances by which the nation's longed-for independence could be expressed. Therefore, right from its inception the Hungarian (national) theatre in Pest was connected to politics, especially national politics. $^{4}$

The theatre was not only used for disguised, or overt, political purposes but played a significant role as a cultural institution. Since the renewal and usage of Hungarian deemed important for everyday life and for national survival, the theatre was also connected to creating, spreading and maintaining language through playing foreign dramas in translation, adapting them to Hungarian circumstances, presenting "original" national dramas, and establishing a national repertoire. One of its main functions was also to discover an event in Hungary's past that would prove effective for communicating the nation's heroic history. Thus it could be used for articulating and remembering a once distinguished Hungarian past with which the much-desired Hungarian independence could be achieved and dominance over some of the Habsburg monarchy's other ethnic groups, such as the Serbs, the Croats, the Romanians, and the Bulgarians, could be maintained and legitimated.

In addition, the political and cultural functions were connected to moral and social ones. Contemporaries saw the theatre as necessary to establish and represent the characteristics of the 'good' Hungarian citizen/patriot. The theatre was to prepare the members of the audience for the roles that they would need to play in a reformed and modernised capitalist society, while at the same time maintaining their national character. The theatre was also to express and to show the appropriate costumes, habits and behaviours of the day. At the same time it was to propagate current political and social views through contemporary Hungarian and foreign dramas (see Kerényi 1990:259-263 and 1999:40).

Due to the limited number of seats the Hungarian (national) theatre could not operate as a business venture. Thus, right from its inception and for its own legiti- 
misation and financial security, it was (financially) supported by the national government. Therefore, the national theatre functioned as political institution and was regarded as a political phenomenon with obvious political purposes. Performing in the national language, establishing national character, and creating a national past, it served as a means for forming and maintaining Hungarian national identity. Consequently, the Hungarian national theatre was initiated and later utilised as a multifunctional national phenomenon and was seen as a semiotised institution with political, cultural, and moral functions, which were connected to national identity and survival. Later, these functions were consciously preserved, remembered and/or even (re)u(tili)sed for national purposes when the existence of Hungary as an independent state was threatened after 1849. It was also expected to (re)define its cultural, political, and moral status and its national identity, after the Treaty of Trianon in 1920. Therefore, the national theatre has been connected closely to national politics, national culture and national identity.

In the 1928 debate, the national canon and the national theatre met in national politics. In this debate, I would like to focus on the dispute over a new mise en scène of a by-then Hungarian national drama in the Hungarian National Theatre in the specific cultural, political and social context of Hungary during the late 1920 s.

\section{National Canon - National Theatre in Hungary: the Debate over Bánk bán in 1928}

From MP Jánossy's speech, it is clear that by 1928 Katona's text was not considered merely as a dramatic text, but it was understood to be canonical in various ways. Thus, before investigating the debate in 1928, I want to sketch the progress of the play to canonical status by mentioning some of the "key" players both on and off the stage. The canonisation of Katona's text and its performance in the National Theatre combine literary, theatrical, institutional, political, cultural and social practices, strategies, and institutions. It demonstrates how a dramatic text could become a national tragedy in literature, how it was canonised as national dramatic text in the theatre, and how by merging literary, institutional, social, political, cultural and theatrical factors, it came to be regarded as a national celebration of Hungarian culture.

\section{Bánk bán till 1928}

The first version of Bánk bán $n^{5}$ as a literary text was submitted to a drama competition sponsored by Erdélyi Múzeum, a literary periodical. The aim of the contest was to find an appropriate play for the opening the first permanent theatre 
in Kolozsvár. Bánk bán, however, was at first ignored. Rewritten, it was allowed to be published in 1820 by the author himself, but the Austrian censor prohibited it from the stage and condemned it for inciting hatred against the Habsburgs. Its premier was on 15 February 1833 in Kassa, as a benefit performance for Gábor Egressy, one of the leading actors of the company. By 1835 it had been performed only three times by the same company, while Kotzebue's plays were given twentythree times in 1833, forty-four times in 1834, and thirty-three times in 1835 . Its first performance in the Pesti Magyar Theatre (from 1840 the National Theatre) was given on 23 March 1839 again as an Egressy's benefit production. After that performance, it was not presented again until 1845 . Then it became a part of the repertoire, although its average number of performances did not exceed five per year. Yet the Bánk bán became part of public knowledge, the theatre performed it, while the spectators came to see it year after year. Its road toward canonisation received a boost when it was performed as a part of the celebration on the night when the Revolution of 1848 broke out in Pest on 15 March. Only the first act was performed; and the play was followed by the National Song written by Sándor Petôfi and the declaration of the aims and claims of the revolution, expressed in Twelve Points or What the Hungarian Nation Wishes. After that the performance of Bánk bán came to be identified with the revolutionary occasion. Consequently, after the failure of the Revolution of 1848, it was banned and would not be played until 1858. The renewed performances were then connected to the memory of the heroic days of the Revolution. Its ten-year prohibition only helped to reinforce the process of associating the play with the Revolution; and Bánk bán came to be considered as part of the passive resistance against the Habsburg regime. Until 1867 and then during the Compromise between the Habsburg monarchy and Hungary, the performance of Bánk bán was not simply concerned with a mise en scène of a literary text as a theatrical performance, but as an important part in the preservation of Hungarian cultural memory it was considered as an expression of both Hungarian independence and the benevolence of the revolution. These memories were reinforced by the fact that the theatre fixed the dramatic text and its mise en scène as first used by Egressy in 1839 (see Orosz 1979 and 1984).

Parallel to its canonical status in the theatre, by then it had been accepted by the literary elite as the drama that embodied the national tragedy. Before 1848 the critics had not appreciated Bánk bán (see Vörösmarty 1969:205-206 for instance). The critical acceptance of József Katona's play began with a piece by Ágost Greguss in 1854. Other writers such as János Arany, the poet laureate, Pál Gyulai, a prominent critic, and Károly Szász, a translator and influential literary critic, soon joined their appreciative voices to that of Greguss. But Szász never completed his analysis, while Arany's piece remained in fragment and was only published in 1879. Gyulai on the other hand gave his inaugural lecture on Bánk bán when he became 
a member of the Hungarian Academy of Sciences. In that lecture, published in 1860, he designated Bánk bán as the Hungarian national tragedy (see Orosz 1999:36-45 and 49-51).

After 1860, the play's literary acceptance and theatrical status was reflected in the fact that the text became part of the national curriculum in primary and secondary schools, as well as in higher education. Textbooks and sourcebooks on Hungarian literature provided detailed surveys of Katona's life, analyses of his Bánk bán, and often inserted scenes from the play that were to be learned by heart. The text with different commentaries was regularly republished in various series of the national writers, or of famous Hungarian writers. In addition, each monograph written on the history of Hungarian literature, theatre, and drama had a chapter on Katona and his Bánk bán (see Orosz 1983:513-532).

Consequently, Katona and his Bánk bán had become a part of the Hungarian literary canon by the last quarter of the nineteenth century. The text and its interpretations were available in various editions. Its performances, with a formally accepted dramatic text and mise en scène, could regularly be seen in the National Theatre on national celebration days such as 15 March and 6 October, as well as during the opening and closing performances of the theatrical season.

\section{The Debate - Over Theatre (?)}

Two years before the centenary celebration (sic!) of Katona's death, Sándor Hevesi, the director of the National Theatre, stated his desire to make dramaturgical changes in the text and to re-direct its mise en scène. Earlier Hevesi had expressed some serious reservations about Bánk bán (1896:36-50). In an interview, published on 21 October 1928, Hevesi had noted that Bánk bán was "supposed to be the best Hungarian classical tragedy. Nevertheless, the play has not enjoyed much theatrical success" (quoted in Németh 1928:183). Hevesi was well aware of the canonical status of the text, and he had accepted this; but he also expressed dissatisfaction with how it had still been performed in the National Theatre during the 1920s. He clearly articulated his wish that in the future "it would not be played once or twice a year merely as a rite of reverence for the young, but it should be performed as a huge theatrical success" (quoted in Németh 1935:183). This could be achieved, Hevesi argued, "when the piece is totally re-arranged and undergoes serious dramaturgical changes. With these changes the piece will be ... a popular success as well" (quoted in Németh 1935:183). Hevesi's plan to re-make Bánk bán can best be understood as part of the modernist attempt to revolt against tradition that began among theatre directors during the last quarter of the nineteenth century. 
Hevesi's position as an artistic leader in the Hungarian theatrical reform movement, the Thália Társaság, helps to explain his ideas on Bánk bán. The Thália Társaság, initiated in 1904 with László Bánóczy, Marcell Benedek, György Lukács served as the center of the reform movement; and the Thália Társaság appeared with two connected aims designed to renew the Hungarian dramatic canon,

occasionally performing such old and new plays which cannot be found in the repertoires of theatres of [Budapest], but which possess great artistic and cultural values and interests; [and to renew the methods in acting and directing in the staging of these plays] by the [Társaság's] own efforts and sources, in which professional actors or actors under contract cannot take part (Thália in Gábor 1988:64) [my translation, Z. I.].

Therefore, the Thália Társaság, like the other European independent theatres, including André Antoine's Théatre Libre in Paris, or Otto Brahm's Freie Bühne in Berlin, presented plays by modern naturalist, symbolist, and secessionist authors such as Hauptman, D’Annunzio, Ibsen, Strindberg, Wedekind, Schnitzler, Giacosa, Mirbeau, Alma Tadema and others. Their works were usually translated by the members of the company, which also propagated new Hungarian plays for the stage. Their mise en scéne and the acting were recognised by contemporaries as modern and were shaped as an "organic whole" by the overall concepts of director Sándor Hevesi. Having published various articles on theatre and drama, Hevesi was invited, before he joined the Thália's company, to become a director's assistant at the National Theatre. Actually, he was the only member of the Thália's artistic leaders, who had had some previous experience working in the theatre. In his mise en scènes Hevesi used the various methods that he had observed on his visits to contemporary European theatres. But in order to explore the possibilities of the text in performance, he kept the theatrical interpretation subservient to the authority of the dramatic text. The company consisted of amateurs as well as young professional actors and actresses who had been brought up in the school of the association and trained by the director during a relatively long rehearsal period. The rehearsals could often last more than two months.

The Thália adapted to the Hungarian stage the canon of modern Western European drama and theatre and incorporated its acting and staging methods. In their productions, however, the main emphasis fell on the text, which was often formally published by the time of the premiere. This revealed the literary preponderance of the context in which Thália operated and came to be later much appreciated. The performance was totally subordinated to the pre-written text, the director to the playwright, and the actor to the character. The notion and scope of the reforms, however significant, were situated within that traditional structure. They 
did not question, rather strengthened, the supremacy of the written text, the hierarchy of the stage, and the relevance of the entire logocentric of theological structure. In consequence of this, even when the company still existed, its achievements could be continuously incorporated into the institutionalised theatres of the day, employing their actors and directors, inserting the acceptable dramas of the Thalia into their own repertoires, and using some of the Thalia's methods in their own rehearsals. When the Thália actually ended in 1908, it was quickly absorbed into the official Hungarian theatre system, which was being reformed within the existing logocentric structure that thus remained unperturbed until the 1930s.

Hevesi was also absorbed by the official theatre system. He went back to the National Theatre where he became the director from 1922 to 1932. By the late 1920s he had attempted to establish in the National Theatre the practice, which had been developed earlier in the Thália Company. For that practice, the repetition of the mise en scène of a classical text, handed down over generations, was intolerable. For this would make the play a museum piece rather than a living theatre. What Hevesi attempted can thus be understood as the negation of a tradition, which he considered already dead, and the re-interpretation, or the reanimation, of a classical dramatic text for the contemporary stage.

\section{The Debate - Over Identity and Legitimisation}

The lively debate over Hevesi's plan and the various, mostly negative, reactions against both theatrical and textual changes, expressed most clearly by MP Jánossy, throw light on the complexity of the situation. Hevesi was not the head of a small and independent alternative theatre company. Instead, he was the director of a national institution; and he had to face the fact that the institution, which he led, was deeply embedded in the complex political, cultural and social matrix of the time. The status of Bánk Bán in that complex matrix can be addressed through Jan Assmann's concept of ritual and textual coherency.

In Das kulturelle Gedächtnis, Assmann argues that past and knowledge, providing identity and coherency for a community, are formed not only by the various formations of memory, but also by cultural practices. Analysing the practices of cultural reproduction of past and knowledge, Assmann differentiates between ritual and textual coherency. In ritual coherency, the location of knowledge is the rite in which knowledge is staged as a sacred recitation. Only with the exact delivery of the order of the rite, the world can be ordered, seen meaningful and authorised. Otherwise it will immediately collapse. Though rite reproduces a given order without modification to its previous executions, its repetition is not the only exact reproduction as it brings its sacred meaning into present. As Assmann points 
out, "the ritual repetition is only the form of meaning, which preserves and brings it into presence." "Since rite continuously refers to memory, its meaning falls into both the absolute past of the gods and the relative past of history (Assmann 1992: 90-91).

Textual coherency appears when an oral community is transformed by writing. Then coherency of existence is not located exclusively in ritual repetition, but provided by written texts as knowledge is located in canonised, founding texts and their interpretations. Within textual coherency, Assmann, however, distinguishes between sacred and canonised texts. In the former, ritual coherency is transplanted in the textual as it is also handed down literally, because it does not endure variation. As Assmann argues, the sacred text is a sort of lingual temple, the appearance of sanctity in the medium of human voice. The sacred text demands not interpretation, but rather recitation, defended by ritual with consideration of the exact regulation of location, time, cleanness and so on (Assmann 1999:94). As opposed to sacred, canonical text is considered as the representation of normative and formative values of a community, therefore the "Truth." "As the fixed letter cannot at all be changed, while the human world is in constant change, there is a distance between the fixed letter and changeable reality, which can only be bridged by interpretation." ${ }^{\prime 7}$ The canonical text needs interpretators as its meanings can only emerge through the threefold relation between text - interpretator listener. Thus

\footnotetext{
the normative and formative impulses of cultural memory can only be attained through the constantly and continuously renewed and reinvented interpretation of the textual tradition which establishes identity. Interpretation thus becomes the gesture of memory, the interpretator remembers, and reminds us of the truth, already forgot$\operatorname{ten}^{8}$ [my translation, Z. I.].
}

Jánossy's speech can be located in textual coherency, but he considered Bánk bán above all as a sacred text and its performance in the National Theatre as a rite: the ritual delivery of the sacred text. For him, that sacred text needed literal repetition in which the performance is about to reproduce the text written by the author, minimising the differences between the two media, caused by the transition from text to performance. The fixed and canonised mise en scène of Bánk bán was thus seen as a rite, handed down from generation to generation as the appropriate and traditional custom. Therefore, the sacred text in ritual performance enforced the continuity and security of national identity and cultural memory.

The problem of national past and national identity was especially acute in the political, social and cultural milieu of the late 1920s. That milieu was basically defined by two factors: Hungary had been defeated in World War I, and in consequence of this, she had been forced to sign the Treaty of Trianon. The Trianon 
Treaty cut off three million Hungarians from the mother country, along with two thirds of the country's pre-World War I territory, and caused severe economic, bureaucratic, social, and cultural problems. The newly formed countries surrounding Hungary (Czechoslovakia, Romania, the Serb-Croat-Slovene Kingdom) formed the Small-Antante and its politics separated Hungary internationally. Apart from that, Hungary was ordered to pay a huge amount for compensation of the damage caused in the war. By the middle of the 1920s, the country's economic, political, and social state had been more or less stabilised. Hungary was independent, but its territory, power, and respect were only a fragmentary of its pre-World War I. Moreover, the Treaty rendered much of the Hungarian cultural heritage inaccessible. Countless places of memory, including institutions, topographical sites, objects, and buildings, were lost and there was little evidence of any continuity. That was a situation in which Hungary was to re-define itself (see Romsics 2000:127-203 and Bertényi-Gyapay 1997:514-540).

The Hungarian state's official ideology, elaborated to redesign national state and identity, was organised around two basic principles known as "Szegedi Gondolat," or the Szeged Ideal and the "Szent-István Gondolat," or St. Stephen Ideal. The former heralded "Christian-national" values and traditions, as well as independence (Szegedy-Maszák 1999:430). The latter emphasized that Hungary's mission was to unite the various ethnic nationals under its own leadership (Bertényi-Gyapay 1997:537). The revision of Trianon remained as a hope that the historical Hungary would be re-created within a few years ${ }^{9}$ (Bertényi-Gyapay 1997:520). Therefore, cultural creations, canons, social habits, institutions, and sites were officially utilised to maintain the memory of historical Hungary and to create a national identity on this basis.

Consequently, for a conservative national politician like Jánossy, Katona's Bánk bán was seen in the theatre of the nation as a piece of continuity. For him and many others, the precise delivery of the text, used by the earlier generations, and the rituality of the performance served to connect the contemporary moment both to the mythical past of Hungary, when Hungary had been regarded as imperial force and possessed the power to conquer; and to the relative past of the Revolution of 1848 and the Reform Era when modern Hungary had been created. For Jánossy, the punctual delivery of the rite was compulsory in order to give coherence and continuity to the present and to establish Hungary and Hungarian national identity. The national theatre, controlled and utilised by official ideology, was thus considered as a monument of the past, recreated in and for the present; and as a lingual temple, where the sacred text is delivered in faithful recitation that displays and reinforces the contract with the selective moments of the heroic past. Furthermore, it indicates to arrange and experience the present and imagines the future along this line. Jánossy's fear of changing the text and its ritual delivery in performance was therefore connected to the fear of changing the national past and 
the national identity. Therefore, Jánossy's argument brought back the ancient use of canon as an instrument that provides orientation and direction.

In his interview and later article Hevesi pointed out the differences between the literary and performance texts of Bánk bán, by referring to the fact that Egressy also adapted it for the stage by cutting and re-arranging the scenes. Therefore, for Hevesi, it was clear that Jánossy was arguing merely for tradition. Hevesi had no intention to change or even slightly alter the national canon. For him, however, Katona's Bánk bán was considered as a canonical text in which knowledge is located. He regarded Bánk bán as a representation of the normative and formative values of a Hungarian community, therefore as the "Truth." But that "Truth" does not open itself up simply by delivering the rite, but through its interpretation. As he argued in an article, written as an answer to the attacks, "the tradition was misunderstood by the national theatre, and it turned into mechanical repetition, not enthusiastic re-creation" (Hevesi in Németh 1935:198). For him, the distance between Katona's and his worlds could only be bridged by the power of interpretation: changing the text dramaturgically and the mise en scène. Only these changes would open up and re-create the meaning of the text. These changes, however, would have re-defined, or at least re-considered the past, including the ritual celebration attached to the previous mise en scène and the tradition within and outside the theatre, and therefore national identity itself.

\section{Conclusions - Performing History/Performing Memory in the Contemporary Present}

Due to the huge outcry, Hevesi only partly realised his plan. He made some minor dramaturgical changes and had the scenery and costumes redesigned. The performance of Bánk bán with the new mise en scène served as a part of the national celebration of Katona's Centenary on 2 April 1930. The celebration was centred in Kecskemét, Katona's birthplace. On the commemorative day various articles, essays, pictures, reports, interviews appeared in the local and national press, while Katona was honored with a public statue in the central square of Kecskemét. MP Jánossy had been correct two years earlier when he had predicted that Katona would turn over in his grave. On 2 April 1930 he actually did turn over in his grave when he was exhumed and later reburied in a honorary grave with a Roman Catholic liturgy. On the same night, the company of the National Theatre played Hevesi's altered mise en scène of Bánk bán in the local theatre of Kecskemét. The following day local and national dignities gave memorial speeches and inaugurated Katona's memorial room in the museum of Kecskemét. ${ }^{10}$

With Katona's exhumation a slice of the past had been brought to light and then buried again in the contemporary present. With that slice, the past was con- 
sciously re-constructed from the present and for the present. The reburial constituted a gesture toward continuity between the past and the contemporary present. The centenary celebrations performed history in which the history of a heroic and mythical Hungarian past, the history of early nineteenth-century Hungary, and the history of the day in 1930 merged. The centenary celebrations also performed a memory in which cultural memory was inscribed in Katona's life, time, and text. That performed memory was consciously utilised as a memory of and reminder to the past, while its performance in the presence established continuity between the past and the contemporary present. Therefore, Katona and his text were officially utilised as legitimisation for the contemporary present. The question of whether it had been an exercise in nostalgia, which aimed to re-create the past in the present as mimesis, hence as an exact imitation, or as a negotiation about its meaning in the present is still debatable, though.

\section{Notes}

1. All the extracts from Assmann's book are given in my translation.

2. "Die Vergangenheit nun, ...; entsteht überhaupt erst dadurch, daß man sich auf sie bezieht" (Assmann 1992:31).

3. "Denn die Heiligung einer bestimmten Tradition läuft immer auf die Heiligung einer bestimmten Gemeinschaft hinaus. Aus dem neutralen Orientierungsinstrument Kanon wird dann eine Überlebensstrategie kultureller Identität” (Assmann 1992:127).

4. The theatre established in 1837 was called Pesti Magyar Színház (Hungarian Theatre of Pest), then it was renamed as National Theatre in 1840.

5. For those who are not familiar with the text, Joseph Reményi summarises it in Hungarian Writers and Literature: Bánk bán, written in iambic meter, consists of five acts. The central character, Bánk banus, is a medieval nobleman of lofty ideas. The background of the plot is Hungarian Kingdom in the year 1213. The country, surrounded by hostile forces, is in a tragic position; the people are poor and downtrodden; the king, Endre II, is engaged in warfare abroad. His wife, Gertrudis, a former German princess, disregards her duties as the mate of a Hungarian ruler; she prefers the entourage of her German kinsmen. Banus Petur, a patriotic nobleman, considers her an enemy of the nation. With other discontented noblemen he organizes a plot against the queen. Petur and his plotting collaborators feel morally justified in their plan. Prince Otto, the brother of the Queen, is infatuated with Melinda, the wife of Bánk, the Hungarian palatine. Bánk, as a loyal servant of the king, decides to disarm the plotters. Meanwhile he discovers that his wife has been attacked by Otto, and it seems to him that the queen condoned her brother's act. Of course, he is outraged, forgets prudence and loyalty and murders the queen, who in fact knew nothing of her brother's intent to dishonor Bánk's wife. The play ends with Melinda's becoming mad, Otto escaping from the court, and with the return of the king abroad. His warriors assassinate Petur. Although the king forgives Bánk, his conscience tortures him. He is punished by his own deed, and sees himself as a murderer who lost the ethical basis of his life (Reményi 1964:63-64).

6. "Die rituelle Wiederholung ist nur die Form für den Sinn, der in ihr bewarth und vergegenwärtigt wird" (Assmann 1992:90). 
7. "Weil der Buchstabe fest ist und kein Jota geändert werden darf, weil aber andererseits die Welt des Menschen fortwährendem Wandel unterworfen ist, besteht eine Distanz zwischen festgestelltem Text und wandelbarer Wirklichkeit, die nur durch Deutung zu überbrücken ist" (Assmann 1992:96).

8. "Die normativen und formativen Impulse des Kulturellen Gedächtnisses können nur durch unausgesetzte, immer erneuerte Textauslegung der identitätsfundierenden Überlieferung abgewonnen werden. Deutung wird zum Gestus der Erinnerung, der Interpret zum Erinnerer, zum Anmahner einer vergessenen Wahrheit" (Assmann 1992:96).

9. That concept was based on A. F. Millerand's letter, attached to the Treaty of Trianon, in which there was the possibility of its future reconsideration; and also on the separate peace agreement with the USA, which had no references to territorial claims, and fueled from time to time by Hungarian and foreign articles and speeches, such as Lord H. S. Rothermere's article on Hungary's revision in the Daily Mail on 21 June 1927 (Bertényi-Gyapay 1997:520 and 524).

10. For the centenary celebrations see Hajnóczy (1930), and Németh (1935:199-208).

\section{References}

Anderson, Benedict (1983). Imagined Communities: Reflections on the Origin and Spread of Nationalism. London: Verso.

Assmann, Jan (1992). Das kulturelle Gedächtnis. Schrift, Erinnerung und politsche Identität in frühen Hochkulturen. München: Verlag C. H. Beck.

Bertényi, Iván and Gábor Gyapay (1997). Magyarország rövid története. Budapest: Maecenas.

Bezeczky, Gábor (1998). "Kánon és trópus” Helikon (3):261-267.

Brown, John Russell, (ed) (1995). The Oxford Illustrated History of Theatre. Oxford and New York: Oxford University Press.

Carlson, Marvin (1989a). "Theatre Audiences and the Reading of Performance." In Thomas Postelwait and Bruce A. McConachie (ed) (1989) Interpreting the Theatrical Past, 82-98.

- (1989b). Places of Performance - The Semiotics of Theatre Architecture. Ithaca and London: Cornell University Press.

-é-á (1928). “A Bánk bán-vita.” Irodalomtörténet (7-8):330-341.

Gábor, Éva, ed. (1988). A Thália Társaság (1904-1908) - Levelek és dokumentumok. Budapest: MSZI.

Hajnóczy, Iván (1930). Katona emlékkönyv. Kecskemét.

Hevesi, Sándor (1986). “Bánk bán.” In: Dráma és színpad. Budapest: Singer és Wolfner, 36-50.

Hobsbawn, Eric J. (1992 - Hungarian translation 1997). Nations and Nationalism since 1780. Cambridge: Cambridge University Press.

Katona, Ferenc and Tibor Dénes (1954). A Thália Története (1904-1908). Budapest.

Kálmán C., György (1998). “A kis népek kánonjainak vizsgálata.” Helikon (3):251-260.

Kerényi, Ferenc, ed. (1990). Magyar Színháztörténet 1790-1873. Budapest: Akadémiai Kiadó.

- (1999). “A Nemzeti Színház - és amiről nem beszélünk.” Magyar Napló (3):40-42.

Kruger, Loren (1992). The National Stage - Theatre and Cultural Legitimation in England, France, and America. Chicago and London: University of Chicago Press.

Németh, Antal (1935). A Bánk bán száz éve színpadon. Budapest.

Nora, Pierre (1984). Entre mémoire et historie. La problémetique des lieux. In: Les lieux de mémoire. I. La Républic. Sous les direction de Pierre Nora. Paris.

Orosz, László (1999). A Bánk bán értelmezésének története. Budapest: Krónika Nova. 
- (1984). “A Bánk bán nemzeti színházi előadásainak szövege (1867-1929).” Cumania (8):497530 .

- (1983). Katona József: Bánk bán (Kritikai kiadás). Budapest: Akadémiai Kiadó.

- (1979). “A Bánk bán nemzeti színházi előadásainak szövege (1845-1867).” Cumania (6):137166.

Postelwait, Thomas and Bruce A. McConachie, ed. (1989). Interpreting the Theatrical Past. Iowa City: University of Iowa Press.

Reményi, Joseph (1964). Hungarian Writers and Literature. New Brunswick and New Jersey: Rutgers University Press.

Romsics, Ignác (2000). Hungary in the Twentieth Century. Budapest: Corvina and Osiris.

Szegedy-Maszák, Mihály (1999). "Literature and Arts from the Beginning of the 18th Century until Today.” In László Kósa, ed. A Companion to Hungarian Studies. Budapest: Akadémiai Kiadó. -(1992). “A bizony(talan)ság ábrándja: kánonképződés a posztmodern korban.” Literatura (2):119133.

- (1990). "The Rise and Fall of Literary and Artistic Canons." Neohelicon (3):129-159.

Simhandl, Peter (1996 - Hungarian 1999). Theatregeschichte in einen Band. Berlin: Henschel Verlag. Stone, Allucquere Rosane (1995). “A szellem teste.” Replika (1995):17-18, 297-323 (Trans. Anna Boross).

Vörösmarty Mihály Összes Müvei (1969). Dramaturgiai Lapok(XIV). Budapest: Akadémiai Kiadó. 
